\title{
THE EFFECTS OF EATING PATTERN AND PHYSICAL ACTIVITY ON THE RISK OF OBESITY AMONG HIGH SCHOOL STUDENTS IN PALEMBANG, SOUTH SUMATERA
}

\author{
Novdaly Fillamenta \\ Diploma Program in Medical Record and Health Informatics \\ Widya Dharma, Palembang
}

\begin{abstract}
Background: Obesity is a growing global health problem. Obesity typically results from over-eating (especially an unhealthy diet) and lack of exercise. In the modern world with increasingly cheap, high calorie food (example, fast food or junk food), prepared foods that are high in things like salt, sugars or fat, combined with increasingly sedentary lifestyles, increasing urbanization, and changing modes of transportation, obesity has rapidly increased in the last few decades, around the world. Overweight and obese children are likely to stay obese into adulthood and more likely to develop non-communicable diseases like diabetes and cardiovascular diseases. This study aimed to the effects of eating pattern and physical activity on the risk of obesity among high school students in Palembang, South Sumatera.

Subject and Method: This was case control study conducted at a Senior High School in Palembang, South Sumatera. A sample 80 students were selected for this consisting of 40 obese students and 40 normal weight students. The dependent variable was obesity. The independent variables were dietary attitude, eating pattern, and physical activity. Obesity was measured by body mass index. The other data were collected by questionnaire. The data were analyzed by a multiple logistic regression.

Results: The risk of obesity increased with the lack of physical activity ( $O R=5.15$; $\mathrm{p}=0.005)$, poor dietary attitude $(\mathrm{OR}=3.28 ; \mathrm{p}=0.030)$, and poor eating pattern $(\mathrm{OR}=2.96 ; \mathrm{p}=0.046)$.

Conclusion: The risk of obesity in adolescents increases with the lack of physical activities, poor dietary attitude, and poor eating pattern.
\end{abstract}

Keywords: obesity, eating behavior, physical activity

\section{Correspondence:}

Novdaly Fillamenta. Diploma Program in Medical Record and Health Informatics Widya Dharma, Palembang, Jl. Kolonel Haji Barlian No.342, Palembang, South Sumatera. Email: fillamenta@gmail.com. Mobile: 081373668586. 